\title{
Role of cyclosporine in Crohn's disease
}

\author{
CN WILLIAMS, FRCPC, FACP, FACG
}

\begin{abstract}
Cyclosporine A has been shown anecdotally to be useful in Crohn's disease. In most studies, a clinical response is seen within a short time, one to two weeks. A feature common to all studies is frequent relapse shortly after the drug is discontinued. There are problems in dosage and bioavailability with gastrointestinal intolerance, malabsorption and variable absorption. Consequently, there is a requirement for monitoring of blood levels. There is renal toxicity, particularly when prior renal disease is present, when nephrotoxic drugs are used concomitantly and in the elderly. A prospective, placebo controlled, international trial of cyclosporine A in patients with steroid-resistant Crohn's disease was recently published. All patients in this study had active Crohn's disease (Crohn's disease activity index greater than 150). There were 37 patients randomized to cyclosporine and 34 to placebo. The mean age, proportion with prior surgery, disease location, presence of complications and cotreatment was the same in both groups. At 12 weeks, two-thirds of the patients on cyclosporine A had responded, compared to one-third on placebo. The 'therapeutic gain', defined as "difference in effect between treatments", was significant at two weeks and remained so for one, two and three months. There is a steroid-sparing effect with this drug, as with other immunosuppressives used in Crohn's disease - a valuable side effect of this therapy. There is increasing evidence that in patients with Crohn's disease, cyclosporine A may be malabsorbed. It is, therefore, recommended that all patients be given intravenous cyclosporine for at least the first week. Once the response is present, the drug may be switched to the oral route, and a pharmacokinetic profile performed. The drug may need to be given three or four times a day in some Crohn's disease patients. In children, cyclosporine $\mathrm{A}$ absorption appears to be related to the length of the intestine. This has not been determined in adults. Currently, the use of cyclosporine A is limited to patients with steroid-resistant Crohn's disease presenting to tertiary referral centres with appropriate cyclosporine A monitoring facilities. Can J Gastroenterol 1990;4(7):424-427 (pour résumé, voir page 425)
\end{abstract}

Key Words: Crohn's disease, Cyclosporine A, Medical therapy, Review Scotia

Division of Gastroenterology, Department of Medicine, Dalhousie University, Halifax, Nova

Correspondence and reprints: Dr CN Williams, Division of Gastroenterology, Department of Medicine, Dalhousie University, 5849 University Avenue, Halifax, Nova Scotia B3H IW2.

Telephone (902) 494-2333, Fax (902) 494-1624
$\mathrm{C}$ YCLOSPORINE IS A FUNGALMETA. bolite, the action of which is both specific and reversible (1-3). It inter. feres with $T$ cell function by specific receptor binding, leading to cell arrest in the G0-G1 phase and resulting in inhibition of cellular proliferation and lymphokine release. This specific release leads to a diminished produc. tion of interleukin-2 from $\mathrm{T}$ helper cells, and diminished interleukin-1 from macrophages suppressing the cell. mediated immune response.

\section{CYCLOSPORINE AND CROHN'S DISEASE}

Cyclosporine has been used mainly in chronic, active, intractible, steroidresistant Crohn's disease (4-8). It has also been used in patients with pyoder. ma gangrenosum resistant to other forms of treatment (5) and in patients with intractible ulcerative colitis $(9$. 11). It is available orally as a suspension in olive oil $(100 \mathrm{mg} / \mathrm{mL})$ and intra. venously at $50 \mathrm{mg} / \mathrm{mL}$; the latter preparation has been used rectally as a topical preparation in patients with resistant proctitis.

There are problems with dosage, In. itial studies used high doses, equivalent to those used to suppress kidney rejec. tion in renal transplant patients $(4,6,12,13)$. However, side effects were 


\section{Rôle de la ciclosporine A dans la maladie de Crohn}

RESUME: La ciclosporine A s'est avérée utile dans le traitement de la maladie de Crohn. Dans la plupart des études, une réponse clinique est rapidement visible (1 à 2 semaines). La caractéristique commune à toutes les études est la fréquence des récidives peu après l'interruption du traitement. Il existe des problèmes de dosage et de biodisponibilité assortis d'intolérance gastro-intestinale, de malabsorption et d'absorption variable. Il est donc nécessaire de surveiller les taux sanguins. Il y a néphrotoxicité, surtout quand il existe des antécédents d'affection rénale, quand des néphrotoxiques concomitants sont administrés, et chez les personnes âgées. On a récemment publié une étude internationale prospective contrôlée contre placebo sur la ciclosporine administrée aux patients réfractaires aux stéroïdes et porteurs d'une maladie de Crohn active (indice d'activité de la maladie de Crohn supérieur à 150). Parmi les patients randomisés, 37 ont reçu de la ciclosporine et 34 un placebo. L'âge moyen, le pourcentage de chirurgie antérieure, le site de la maladie, la présence de complications et le cotraitement étaient les mêmes dans les deux groupes. A la 12 e semaine, deux-tiers des patients sous ciclosporine avaient répondu au traitement par rapport à un tiers dans le groupe placebo. Le gain thérapeutique, défini comme «la différence entre les effets des traitements", était significatif à la 2e semaine et l'est resté à 1,2 et 3 mois. Il y a un effet d'épargne stéroïde avec ce médicament, tout comme avec les autres - un effet secondaire appréciable. Il semble de plus en plus apparent que la ciclosporine pourrait être mal absorbée chez les patients porteurs d'une maladie de Crohn. L'administration de la ciclosporine par voie intraveineuse au cours de la première semaine est donc recommandée chez tous les patients. Une fois que le patient réagit, il est possible de donner le médicament par voie orale et de tracer un profil pharmacocinétique. Il peut être nécessaire de donner la ciclosporine trois ou quatre fois par jour dans certains cas de maladie de Crohn. Chez les enfants, l'absorption semble liée à la longueur de l'intestin, phénomène qui n'a pas été déterminé chez les adultes. Présentement, l'usage de la ciclosporine est limitée aux patients souffrant d'une maladie de Crohn et résistant aux stéroïdes qui se présentent dans les établissements spécialisés en mesure d'effectuer une surveillance appropriée.

common and there was a high drop-out rate from these early studies. There is also a problem with bioavailability with gastrointestinal intolerance, malabsorption and variable absorption (14). There is a requirement for monitoring of blood levels and renal toxicity which is dependent on age, the coadministration of other agents (for instance nonsteroidal anti-inflammatory drugs [NSAIDs]) - when Crohn's disease already affects the kidneys and when there is intrinsic kidney disease.

In a previous study, 15 patients with severe active Crohn's disease, predominantly ileitis and ileocolonic types, were treated with a 16 week course of 5 to $10 \mathrm{mg} / \mathrm{kg}$ body weight per day of cyclosporine (8). Ten patients responded to cyclosporine within four weeks. Three were in remission more than a year later. There was no tapering and no fistulas were closed in these patients. In another study of 11 patients, a lower dose, 5 to $7.5 \mathrm{mg} / \mathrm{kg}$ per day, was used (12). One of these patients had malabsorption of cyclosporine; two had partial malabsorption; eight improved by three months; and three were in remission at three months. The steroids were tapered in this and in the previous open study. A third open study (4) included seven patients with a similar distribution of disease using a dose of 4.5 to $10 \mathrm{mg} / \mathrm{kg}$ cyclosporine per day; there was no tapering of the dose. Six patients responded in two to four weeks, and five relapsed either on or within one week of stopping the cyclosporine.

These pilot studies led to a randomized, prospective, double-blind, placebo controlled, 12 week trial stratified for steroid use (7). The initial dose of cyclosporine was 5 to $7.5 \mathrm{mg} / \mathrm{kg}$ body weight per day given twice a day, with careful monitoring of $12 \mathrm{~h}$ trough levels. There was a dose reduction if creatinine rose by more than $50 \%$ or if it went above an absolute value of 140 $\mu \mathrm{mol} / \mathrm{L}$. Similarly, the dose was reduced if potassium rose above $5 \mathrm{mEq} / \mathrm{L}$ or blood pressure rose despite treatment. The maximum dose used was 15 $\mathrm{mg} / \mathrm{kg}$ body weight per day. Disease activity was monitored by a modified Present score (15), using the following parameters: well-being, symptoms and signs, activity (ie, the presence of fistulas, fissures, abscesses), and possible individual goals. The baseline was 0 . Any improvement was recognized on a graded scale of $1+$ to $3+$, and any worsening on a negative scale of 1 - to 3 -. The mean therapeutic Present score was modified by exclusion of the prednisone rating as the prednisone dose was not changed, and a summed score rather than a mean was used. Secondary measures in this trial included plasma orosomucoid and Crohn's disease activity index (CDAI) (16).

At three months, 22 of 37 patients (59\%) randomized to cyclosporine improved compared to 11 of 34 patients (32\%) randomized to placebo $(\mathrm{P}=0.032)$. The cyclosporine was kept constant for three months and then tapered over a further three months. At the end of six months, of the 37 patients in the cyclosporine A group, $14(38 \%)$ continued to improve compared to five of the 35 placebo patients $(15 \%) \quad(P=0.034)$. Side effects were present but were not of sufficient magnitude to necessitate withdrawal of any patient (Table 1). The median plasma creatinine was $80 \mu \mathrm{mol} / \mathrm{L}$ (range 50 to 121 ), rising to $89 \mu \mathrm{mol} / \mathrm{L}$ (range 54 to 150) at three months. Plasma potassium similarly rose from a median of 4.1 $\mathrm{mEq} / \mathrm{L}$ (range 2.9 to 4.8 ) initially, to $4.2 \mathrm{mEq} / \mathrm{L}$ (range 3.4 to 5.1 ) at three months. Hematocrit was 0.37 (range 0.27 to 0.44 ) initially, falling to 0.35 (range 0.27 to 0.45 ) at three months. Seven patients in the cyclosporine group and two in the placebo group had an increase in plasma creatinine or plasma potassium. One patient in the cyclosporine group and two in the placebo group had complete malab. sorption based on blood levels at $12 \mathrm{~h}$. Six patients in the cyclosporine group and one in the placebo group had par- 
TABLE 1

Cyclosporine side effects in Crohn's and autoimmune disease

\begin{tabular}{lccl}
\hline & Crohn's disease & Placebo & Autoimmune disease* \\
\hline Paresthesia & 16 & 4 & Nephrotoxicity \\
Hypertrichosis & 2 & 0 & Hypertension \\
Dyspepsia & 2 & 0 & Hyperkalemia \\
Hypertension & 1 & 0 & Hepatotoxicity \\
Rash & 1 & 1 & Anemia \\
Vertigo & 1 & 1 & Hypertrichosis \\
Diarrhea & 1 & 0 & Gingival hyperplasia \\
& & & Gastrointestinal intolerance \\
& & & Tremor \\
& & & Paresthesias \\
\hline
\end{tabular}

Crohn's disease data from reference 7: "Side effects frequently associated with cyclosporine in autoimmune disease

tial malabsorption. Of the 10 patients with compete or partial malabsorption, five improved and five did not change. Of all patients improving on cyclosporine, one-half did so within two weeks. There was a close correlation of the Present score with the serum orosomucoid, CDAI and van Hees index (17). There was an equal response regardless of whether the small or large bowel was affected.

\section{CYCLOSPORINE IN ULCERATIVE COLITIS}

Cyclosporine has been used in acute ulcerative colitis $(9-11)$. The first of these cases, a 78-year-old female with proctocolitis responded to $12 \mathrm{mg} / \mathrm{kg}$ cyclosporine per day while salazopyrine and prednisone were not effective. However, this patient took six weeks to respond, as judged by indium scan and histological change. She was discharged on $8 \mathrm{mg} / \mathrm{kg}$ cyclosporine per day, however, this was not taken regularly and the disease recurred within five weeks. She responded to retreatment and rectal biopsies subsequently returned to normal. The side effects were shakiness and a painful mouth.

Cyclosporine was used to treat five patients with severe ulcerative colitis unresponsive to steroids in whom total colectomy was imminent (10). All responded to initial doses of 10 $\mathrm{mg} / \mathrm{kg} /$ day after four to six weeks of therapy. Salazopyrine or steroids were then used. Follow-up was one to four months with one relapse at three months.

In the largest study reported in abstract form (11), cyclosporine was used to treat severe, refractory ulcerative colitis. Ten hospitalized patients with severe, refractory ulcerative colitis were given cyclosporine intravenously, titrating to full blood levels of 400 to $600 \mathrm{ng} / \mathrm{mL}$. All of the patients had failed on 10 to 14 days of parenteral steroids and were advised to undergo colectomy. The patients were maintained on parenteral cyclosporine for 10 to 12 days and, if improved, were discharged on oral cyclosporine, 4 to 8 $\mathrm{mg} / \mathrm{kg} /$ day, with continued monitoring for six months. Failures were advised to have a colectomy.

Ten patients (mean age 29 years) were treated; seven had universal and three left-sided disease. The mean duration of disease was six years. Six patients showed marked improvement with intravenous cyclosporine and were discharged on oral cyclosporine. The mean response time was 9.7 days. Of the six who responded, three were in clinical remission at six months, having stopped both cyclosporine and steroids; two were responding partially and one patient who relapsed after five months' remission underwent elective colectomy. Of the four failures, three underwent colectomy and one refused surgery and is maintaining high dose steroids. No morbidity or significant renal toxicity was observed with cyclosporine, and in no patient did toxicity require stopping cyclosporine. Thus, $50 \%$ of these patients with severe, refractory ulcerative colitis avoided surgery.

There are no comparison data with other immunosuppressive drugs (azathioprine, 6-mercaptopurine), and none with the newer 5 -aminosalicylic acid (5-ASA) compounds versus cyclosporine in patients with Crohn's disease or in ulcerative colitis.

\section{CURRENT RECOMMENDATIONS}

The author's current protocol for patients with severe, resistant, intractible Crohn's disease is to overcome malabsorption problems by giving cyclosporine intravenously, using a dose of $2.5 \mathrm{mg} / \mathrm{kg} /$ day and adjusting the dose to give blood levels in the $275 \pm 125 \mathrm{ng} / \mathrm{mL}$ range, using a specific monoclonal antibody radioimmuno. assay technique (Inestar; Cyclo-trac whole blood cyclosporine A assay). After the clinical response is seen, the dose is changed to oral cyclosporine 5 $\mathrm{mg} / \mathrm{kg} /$ day in divided doses. After the pharmacokinetic profile, $12 \mathrm{~h}$ dosing is usually effective, with occasional patients requiring multiple doses. Treatment is discontinued at four weeks if there is no response. Therapy is maintained for at least three to six months with oral 5-ASA, and switched to another immunosuppressive agent, mainly azathioprine. The mean time for response to azathioprine is three months. Consequently, the cyclo. sporine is maintained during this time to allow azathioprine to take effect. The dose of prednisone is tapered and discontinued.

\section{FUTURE PROSPECTS}

In the future, studies will define the best site for using cyclosporine, and correlation with human lymphocyte antigen or similar genetic markers may help to understand further the pathogenic mechanism of Crohn's disease, as the mechanism of action of cyclosporine is very specific. There may well be iden. tifiable subgroups of patients with Crohn's disease with these genetic markers that will or will not respond to cyclosporine. Cyclosporine is one of the few drugs that can be used when patients develop upper gastrointestinal Crohn's disease. Its role in the main. tenance and prevention of relapse is currently being studied in a multi. 
centre, prospective, placebo controlled, Canadian trial. The role of cyclosporine in ulcerative colitis has not yet been determined. It may be of benefit in patients unsuitable for elective colectomy with fulminant disease, particularly when religious considerations prevent replacement of blood. Topical cyclosporine may also be of benefit in patients with resistant ulcerative proctitis. Cost and toxicity of the drug will prevent its widespread use, which should be confined to protocol studies in tertiary referral centres with transplant programs, with the expertise in monitoring and following patients on long term cyclosporine therapy.

ACKNOWLEDGEMENTS: The author thanks DrGerard Murphy, Medical Director of Sandoz Canada Inc, for his generous donation of cyclosporine and continuing support.

\section{REFERENCES}

1. Bunjes Hardic D, Rollinghoff M, Wagner $\mathrm{H}$. Cyclosporin A mediates immunosuppression of primary gtotoxic $T$-cell responses by impairing the releases of interleukin-1 and interleukin-2. Eur J Immunol 1981;11:656-61.

2. Hess AD, Colombani PM. Cyclo- sporine: Mechanism of action in vitro studies. Proc Anal 1986;38:198-221.

3. Borel JF, Ryffel B. The mechanism of action of cyclosporin: A continuing puzzle. In: Schindler R, ed. Cyclosporin in Autoimmune Diseases. Berlin: Springer-Verlag, 1985:24-32.

4. Bianchi PA, Mindelli M, Quarto di Palo F, Ranzi T. Cyclosporin for Crohn's disease. Lancet 1984;ii:1242-3.

5. Marbet UA, Gyr K, Stalder GA. Controlled study of cyclosporin versus corticosteroids in acute Crohn's disease: Methodology and early find. ings. In: Schindler R, ed. Cyclosporin in Autoimmune Diseases. Berlin: Springer-Verlag, 1985:188-9

6. Allison MC, Pounder RE. Cyclosporine for Crohn's disease. Aliment Pharmacol Ther 1987;1:39-43.

7. Brynskov J, Freund L, Rasmussen SN, et al. A placebo-controlled, doubleblind, randomized trial of cyclosporine therapy in active chronic Crohn's disease. N Engl J Med 1989;321:845-50.

8. Peltekian KM, Williams CN, MacDonald AS, Roy PD, Czolpinska E. Open study of cyclosporine in patients with severe active Crohn's dis. ease refractory to conventional therapy. Can J Gastroenterol 1988;2:5. 11.

9. Gupta S, Keshavarzian A, Hodgson HJF. Cyclosporine in ulcerative colitis. Lancet 1984;ii:1277-8.

10. Bianchi Porro G, Panza E, Petrillo M. Cyclosporine $\mathrm{A}$ in acute ulcerative colitis. Ital J Gastroenterol 1987;9:40-1.

11. Lichtiger S, Present DH. Cyclosporine $A$ in the treatment of severe, refractory, ulcerative colitis. Gastroenterology 1989;96:A301.

12. Brynskov J, Launtsen K, Freund L, et al. Clinical experience with cyclosporin (cyclosporin A) in chronically active, therapy resistant Crohn's disease. Gastroenterology 1987;92:1330.

13. Peltekian KM, Williams $\mathrm{CN}$, MacDonald AS, Roy P, Czolpinska E. Open study of cyclosporine in Crohn's disease. Gastroenterology 1987;92:1571.

14. Brynskov J, Binder V, Riis P, et al. Low dose cyclosporine for Crohn's disease: Implications for clinical trials. Aliment Pharmacother 1988;3:135-42.

15. Present DH, Korelitz BI, Wisch N, Glass JL, Sachar AS, Pasterlack BS. Treatment of Crohn's disease with 6 . mercaptopurine: A long-term, randomized, double-blind study. N Engl J Med 1980;302:981-7.

16. Best WR, Becktel JM, Singleton JW, Kern F Jr. Development of Crohn's disease activity index: National cooperative Crohn's disease study. Gastroenterology 1976;70:439-44.

17. van Hees PAM, van Elteran $P$, van Lier HJJ, van Tungeren JHM. An index of inflammatory activity in patients with Crohn's disease. In: Pena AS, Weterman IT, Booth CC, Strober W, eds. Recent Advances in Crohn's Disease. Le Hague: Martinus Nijhoff, 1981:17-24. 


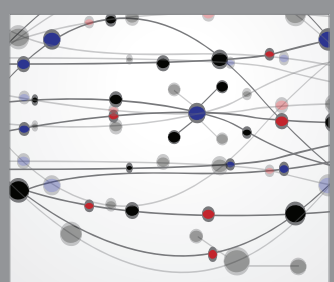

The Scientific World Journal
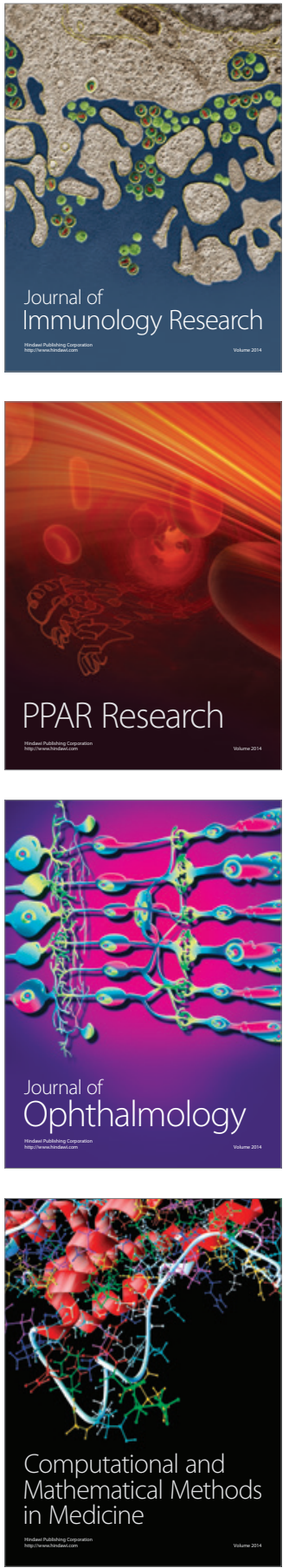

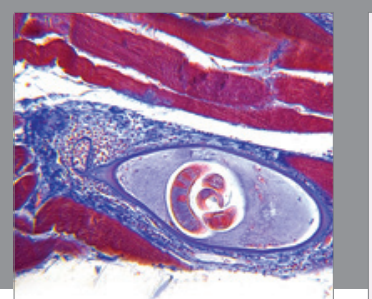

Gastroenterology Research and Practice

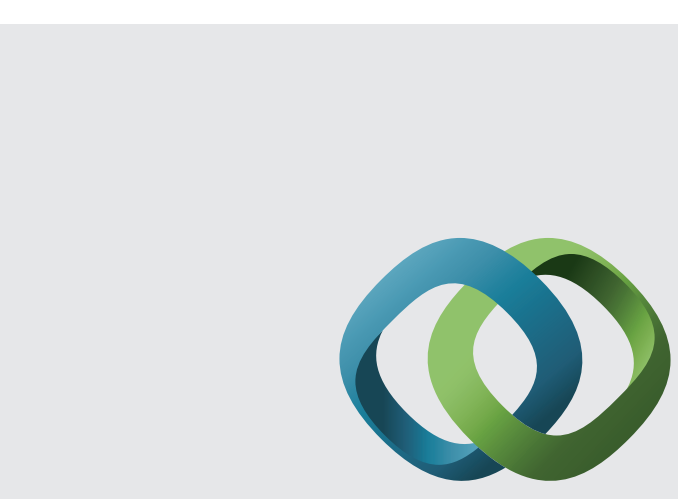

\section{Hindawi}

Submit your manuscripts at

http://www.hindawi.com
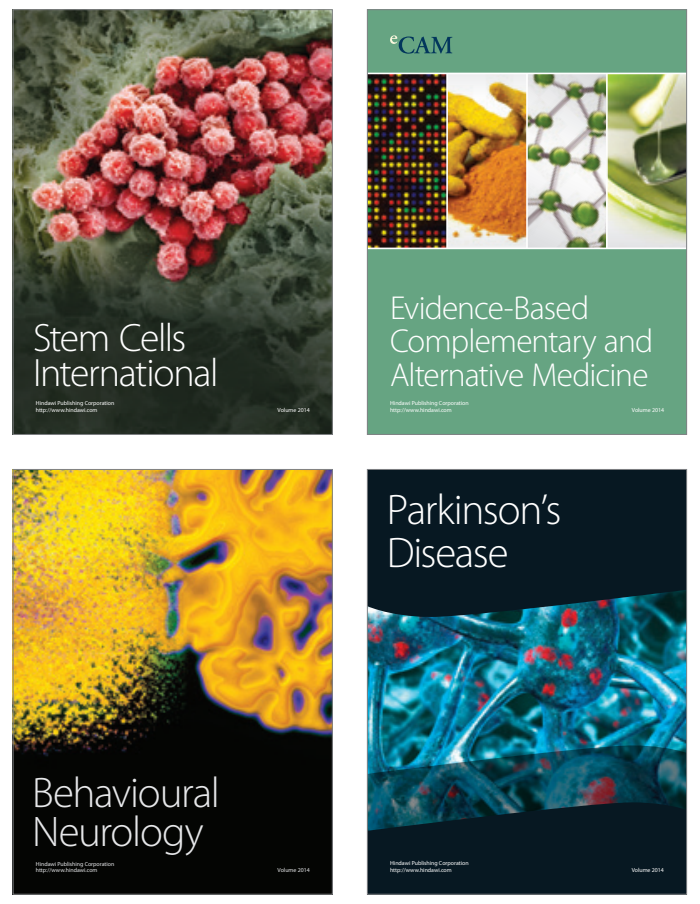
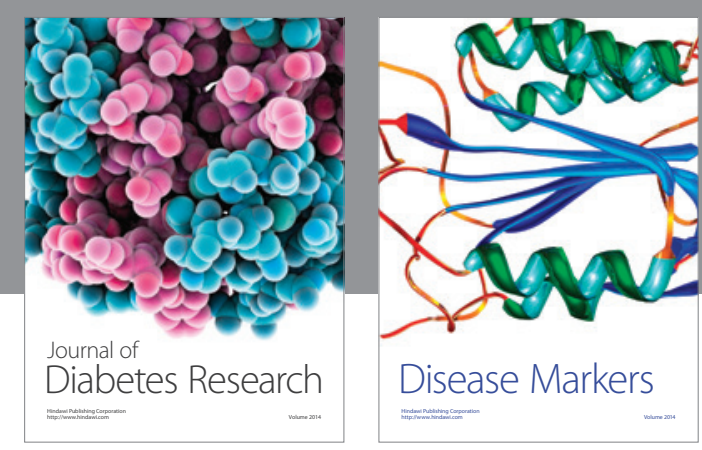

Disease Markers
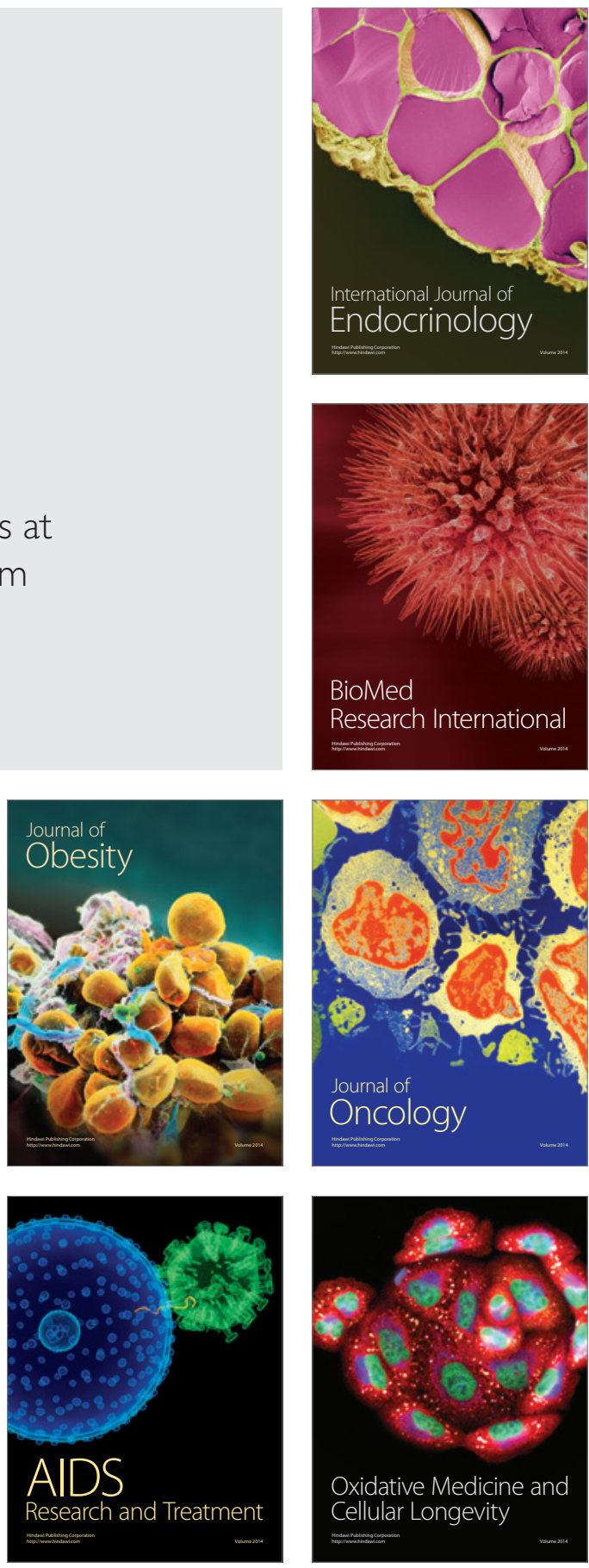